\title{
Yield and Economic Return of Seedling Tuber Derived from True Potato Seed as Influenced by Tuber Size and Plant Spacing
}

\author{
T. S. Roy ${ }^{1, *}$, M. A. Baque ${ }^{1}$, R. Chakraborty ${ }^{1}$, M. N. Haque ${ }^{1}$, P. Suter ${ }^{2}$ \\ ${ }^{1}$ Department of Agronomy, Sher-e-Bangla Agricultural University, Bangladesh \\ ${ }^{2}$ Duk Dia Jay, NGO, Bangladesh
}

Copyright (C) 2015 Horizon Research Publishing All rights reserved.

\begin{abstract}
The experiment was conducted at Agronomy research field of Sher-e-Bangla Agricultural University, Dhaka, during 10 November 2012 to 10 March 2013 to observe the response of seedling tuber weight and plant spacing on yield and economic analysis of potato. Four weight of seedling tubers viz., $40 \pm 2,30 \pm 2,20 \pm 2$ and $10 \pm$ $2 \mathrm{~g}$ and three plant spacing viz., $60 \mathrm{~cm} \times 25 \mathrm{~cm}, 60 \mathrm{~cm} \times 20$ $\mathrm{cm}$ and $60 \mathrm{~cm} \times 15 \mathrm{~cm}$ were used as treatment and laid out in Randomized Complete Block Design (RCBD) with three replications. Results revealed that in general yield attributes such as tubers hill ${ }^{-1}$ and tuber weight and tuber yield of gross, marketable and non-marketable were significantly influenced by seedling tuber weight and plant spacing. The highest tuber yield $\mathrm{ha}^{-1}$ both gross and marketable was recorded in the tuber weight of $30 \pm 2 \mathrm{~g}$ due to increased number of tubers hill- ${ }^{-1}$ and tuber yield hill ${ }^{-1}$ and the lowest from smaller seedling tuber of $10 \pm 2 \mathrm{~g}$. Results showed that tubers hill ${ }^{-1}$, single tuber weight and tuber weight hill ${ }^{-1}$ increased with increasing plant spacing. The highest gross and marketable tuber yield ha ${ }^{-1}$ was observed in the plant spacing of $60 \mathrm{~cm} \times 20 \mathrm{~cm}$ and the lowest from closer spacing of $60 \mathrm{~cm} \times 15 \mathrm{~cm}$. For combined effect of seedling tuber weight and plant spacing, the highest gross and marketable tuber yield was observed in the treatment combination of 40 $\pm 2 \mathrm{~g}$ seed tuber with the plant spacing of $60 \mathrm{~cm} \times 25 \mathrm{~cm}$. But economic point of view with high yield performance, the seedling tuber size of $30 \pm 2 \mathrm{~g}$ with plant spacing of $60 \mathrm{~cm} \times$ $20 \mathrm{~cm}$ was more profitable than those of other treatment combinations.
\end{abstract}

Keywords True Potato Seed, Seedling Tuber, Seed Size, Spacing, Yield, Economic Return

\section{Introduction}

Potato (Solanum tuberosum) is the $4^{\text {th }}$ world crop after wheat, rice and maize. Bangladesh is the $7^{\text {th }}$ potato production country in the world [1]. In Bangladesh, it ranks $2^{\text {nd }}$ after rice in production. The total area under potato crop, national average yield and total production in Bangladesh are 430446 hectares, 19.071 tons ha $^{-1}$ and 8205470 metric tons, respectively. Total production is increasing day by day as such consumption also rapidly increasing in Bangladesh [2].The yield of potato is very low in Bangladesh comparison to 40.16 tha $^{-1}$ in USA, 42.1 tha $^{-1}$ in Denmark and 40.0 tha $^{-1}$ in UK [3], due to the use of low quality seed and use of sub-optimal production practices. Performance of potato can be increased by optimizing use of manure and fertilizer, planting time, spacing and use of optimal sized seed [4]. A good TPS progeny can produce 500 to 800 small tubers ranged from 1 to $45 \mathrm{~g}$ (seedling tuber) in a meter of land when planted at $10 \mathrm{~cm} \times 10 \mathrm{~cm}$ spacing [5].These seedling tubers can be planted as good quality tubers for ware potato production having higher yield potentiality when an optimum planting spacing is used [6]. Till now the farmers of Bangladesh don't know the optimum grade, time, weight of seedling tuber to cultivate commercial. The planting material of potato is very important which are related to the cost. They used bulk amount of tuber by cutting but as a result they spend more money. So from this point of view, this experiment was carried out to optimize the most promising seed size and plant spacing. The seedling derived from true potato seed has performed better with the seed size and plant spacing phenomenon respectively. True potato seed technology could reduce the cost of production mainly during planting of potatoes on the field. With the utilization of optimum seed tuber size and plant spacing of seedling tuber, the farmers could improve their production practices so that they can reduce their cost of cultivation and transportation cost during carrying the bulk tuber instead of true potato seed derived seedling tubers. Trials were conducted in 2001 in Tamil Nadu, India by[7] to investigate suitable agro-techniques for obtaining the maximum number of seed size tubers from potato cultivars Kufri Swarna and Kufri Jyoti. Treatments includes: tuber weights of 10-20, 20-30, 30-40 and 40-50 g; intra row spacings of 10, 15 and $20 \mathrm{~cm}$; and 2 dates of haulm killing (75 and 90 days after planting). The authors reported that in both cultivars, 30-40 
and 20-50 g tubers, might be used at an intra-row spacing of $10 \mathrm{~cm}$, and with haulm killing at 90 days after planting to obtain the maximum number of seed tuber size. Research on seed tuber weight and plant spacing have been found to influence the yield and economic return reported by [7-9].But only a few studies have been done considering size of seedling tubers and plant spacing on the performance of potato in Bangladesh. Therefore, this experiment was undertaken to find out the principle purpose, response of seedling tuber size and spacing on the yield and economic return of potato.

\section{Materials and Methods}

Experiment was carried out at Agronomy research field of Sher-e-Bangla Agricultural University, Dhaka, during 10 November 2012 to 10 March 2013, which was belonging to the Madhupur Tract (AEZ-28). Four seedling size, viz., $\mathrm{T}_{1}=$ $40 \pm 2 \mathrm{~g}, \mathrm{~T}_{1}=30 \pm 2 \mathrm{~g}, \mathrm{~T}_{3}=20 \pm 2 \mathrm{~g}, \mathrm{~T}_{4}=10 \pm 2 \mathrm{~g}$ and three spacing, viz., $S_{1}=60 \mathrm{~cm} \times 25 \mathrm{~cm}, S_{2}=60 \mathrm{~cm} \times 20 \mathrm{~cm}, S_{3}=$ $60 \mathrm{~cm} \times 15 \mathrm{~cm}$ were used as treatment. The experiment was laid out in RCBD (factorial) with three replications. The planting material was the first generation TPS seedling tubers of BARI TPS-1. The size of the unit plot was 2.5 $\mathrm{m} \times 2.0 \mathrm{~m}$. Distances between block to block and plot to plot were $1.0 \mathrm{~m}$ and $0.50 \mathrm{~m}$, respectively. Fertilizer was applied, viz. $320,232,285,120,10,10$ and $10000 \mathrm{~kg} \mathrm{ha}^{-1}$ for urea , TSP, MOP, gypsum, $\mathrm{ZnO}$, boric acid and cow dung respectively. Cowdung was applied 10 days before final land preparation. Total amount of TSP, gypsum, $\mathrm{ZnO}$, boric acid and half of urea and MP were applied at basal doses during final land preparation. The rest $50 \%$ urea and MP were side dressed in two equal splits at 25 and 45(DAP) during first and second earthing up. To protect the young seedlings from the attack of cut worm, soil was treated with Furadan5G@15 kg ha-1. The well sprouted seed tubers were planted on November 10, 2009, at a depth of 5-7 cm in furrow made $60 \mathrm{~cm}$ apart and seed tubers were covered with soil. Two weeding was done, $1^{\text {st }}$ at two weeks after emergence and $2^{\text {nd }}$ was done before $2^{\text {nd }}$ top dressing of urea. Earthing up was done twice during growing period at 25 DAP and 45DAP respectively. Irrigation was done three times at 25 DAP, 45 DAP and 65 DAP throughout the growing period in controlled way. Crop protection measures were taken as and when necessary. Ten sample plants were randomly selected from each plot and tagged separately for recording necessary data and then the whole plot was harvested at 90 DAP with the help of spade. The data were collected on tuber hill ${ }^{-1}$, single tuber weight, tuber yield, grades of potato and benefit cost ratio (BCR). The collected data were analyzed statistically and means were adjusted by using the Duncan's Multiple Range Test.

\section{Results and Discussion}

Result revealed that the number tubers hill ${ }^{-1}$ increased with increasing tuber weight till $30 \pm 2 \mathrm{~g}$ tuber and thereafter further increase tuber weight did not increase tubers hill ${ }^{-1}$ in (Table 1). The highest production of tubers hill ${ }^{-1}$ was observed in the tuber weight of $30 \pm 2 \mathrm{~g}$ (8.07) that was statistically similar to tuber weight of $40 \pm 2 \mathrm{~g}\left(7.70 \mathrm{hill}^{-1}\right)$ and lowest from $10 \pm 2 \mathrm{~g}$ (6.46). Reduction in the tubers hill' ${ }^{-1}$ under smaller weight seed tuber might be due to lesser stems hill $^{-1}[10]$.In Table 1, result showed that tuber number hill $^{-1}$ increased with increasing plant spacing. The highest tubers hill $^{-1}(7.85)$ was recorded in $60 \mathrm{~cm} \times 25 \mathrm{~cm}$ spacing which was statistically similar to $60 \mathrm{~cm} \times 20 \mathrm{~cm}$ spacing (7.57) and lowest from $60 \mathrm{~cm} \times 15 \mathrm{~cm}$ spacing (6.73). Reduction in tuber number in densely populated area might be due to increased number of plants per unit area. This increased number of plants per unit area exerted competition among plants for nutrients and light that caused a reduction in tuber number [11].

Table 1. Effect of seed tuber weight, plant spacing on yield attributes and yield of potato

\begin{tabular}{|c|c|c|c|c|}
\hline Treatments & Tubers hill $^{-1}$ (no.) & Single tuber weight (g) & $\begin{array}{c}\text { Tuber weight } \\
\text { hill }^{-1}(\mathrm{~g})\end{array}$ & $\begin{array}{c}\text { Tuber yield } \\
\left(\mathrm{t} \mathrm{ha}^{-1}\right)\end{array}$ \\
\hline \multicolumn{5}{|c|}{ Tuber weight } \\
\hline $40 \pm 2 \mathrm{~g}$ & $7.70 \mathrm{ab}$ & $52.03 \mathrm{a}$ & $304.1 \mathrm{a}$ & $26.47 \mathrm{a}$ \\
\hline $30 \pm 2 \mathrm{~g}$ & $8.07 \mathrm{a}$ & $52.13 \mathrm{a}$ & $317.2 \mathrm{a}$ & $27.27 \mathrm{a}$ \\
\hline $20 \pm 2 \mathrm{~g}$ & $7.30 \mathrm{~b}$ & $45.29 \mathrm{~b}$ & $248.5 \mathrm{~b}$ & $22.33 \mathrm{~b}$ \\
\hline $10 \pm 2 \mathrm{~g}$ & $6.46 \mathrm{c}$ & $30.13 \mathrm{c}$ & $146.0 \mathrm{c}$ & $16.33 \mathrm{c}$ \\
\hline F-test & $* *$ & $* *$ & $* *$ & $* *$ \\
\hline SE & 0.145 & 1.069 & 7.955 & 0.606 \\
\hline \multicolumn{5}{|c|}{ Spacing } \\
\hline $60 \mathrm{~cm} \times 25 \mathrm{~cm}$ & $7.85 \mathrm{a}$ & $48.70 \mathrm{a}$ & $293.8 \mathrm{a}$ & $23.18 \mathrm{ab}$ \\
\hline $60 \mathrm{~cm} \times 20 \mathrm{~cm}$ & $7.57 \mathrm{a}$ & $44.75 \mathrm{~b}$ & $258.9 \mathrm{~b}$ & $23.92 \mathrm{a}$ \\
\hline $60 \mathrm{~cm} \times 10 \mathrm{~cm}$ & $6.73 \mathrm{~b}$ & $41.24 \mathrm{c}$ & $209.0 \mathrm{c}$ & $22.20 \mathrm{~b}$ \\
\hline F-test & $* *$ & $* *$ & $* *$ & * \\
\hline SE & 0.125 & 0.926 & 6.889 & 0.524 \\
\hline $\mathrm{CV} \%$ & 5.89 & 7.15 & 9.40 & 7.87 \\
\hline
\end{tabular}

In a column means having similar letter(s) are statistically similar and those having dissimilar letter(s) differ significantly at 0.05 level of probability. $* * *$ indicate significant at $5 \%$ and $1 \%$ level of probability, respectively. T1 $=40 \pm 2 \mathrm{~g} ; \mathrm{T} 2=30 \pm 2 \mathrm{~g} ; \mathrm{T} 3=20 \pm 2 \mathrm{~g} ; \mathrm{T} 4=10 \pm 2 \mathrm{~g} ; \mathrm{S} 1=60 \mathrm{~cm} \times 25 \mathrm{~cm} ; \mathrm{S} 2=60$ $\mathrm{cm} \times 20 \mathrm{~cm} ; \mathrm{S} 3=60 \mathrm{~cm} \times 15 \mathrm{~cm}$. 


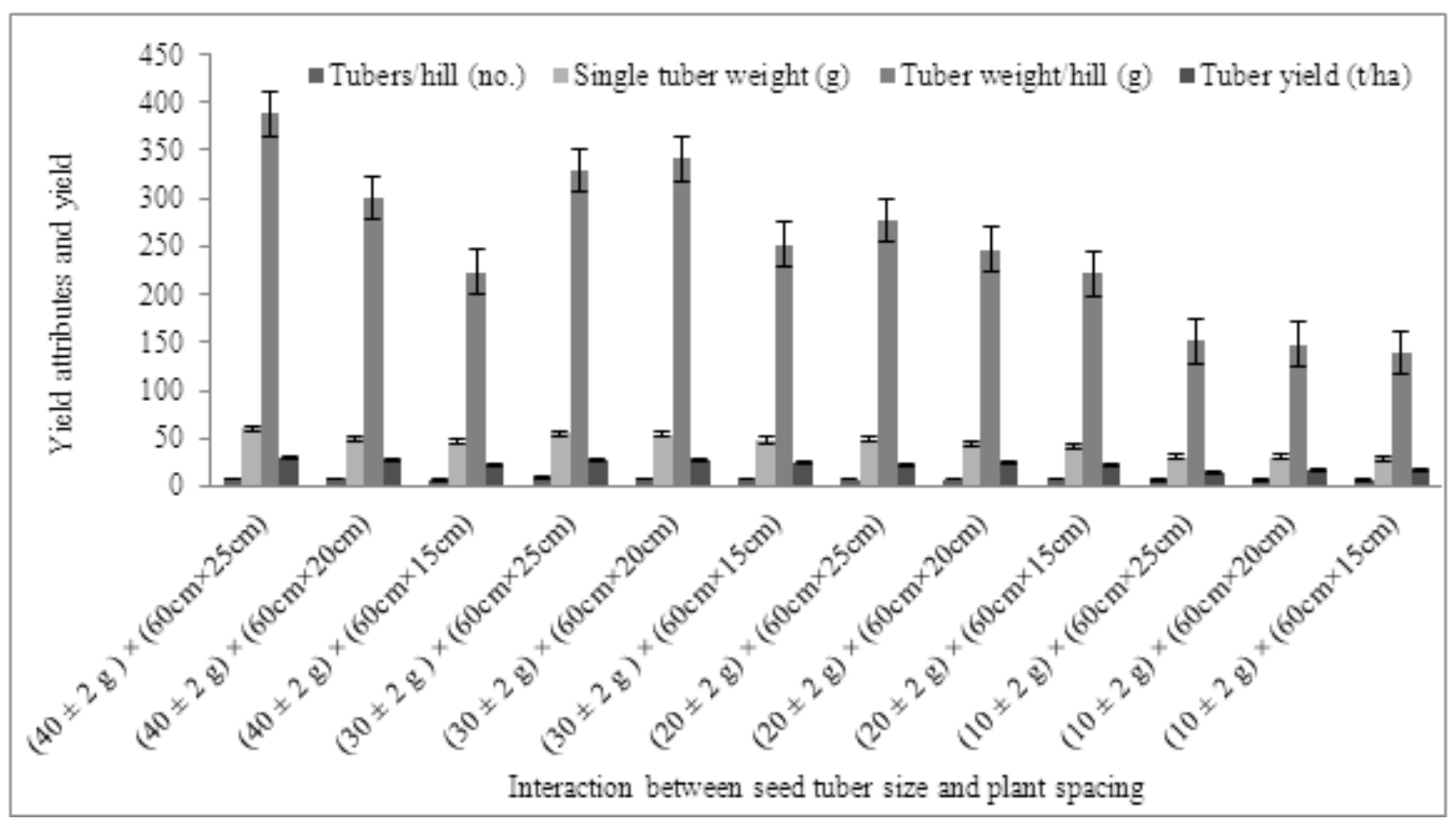

Figure 1. Interaction effect of seed tuber weight and spacing on yield attributes and yield of potato. Vertical bar represent $\mathrm{SE}$ value $(0.251,0.852,13.778$ and 1.049). $\mathrm{T}_{1}=40 \pm 2 \mathrm{~g} ; \mathrm{T}_{2}=30 \pm 2 \mathrm{~g} ; \mathrm{T}_{3}=20 \pm 2 \mathrm{~g} ; \mathrm{T}_{4}=10 \pm 2 \mathrm{~g} ; \mathrm{S}_{1}=60 \mathrm{~cm} \times 25 \mathrm{~cm} ; \mathrm{S}_{2}=60 \mathrm{~cm} \times 20 \mathrm{~cm} ; \mathrm{S}_{3}=60 \mathrm{~cm} \times 15 \mathrm{~cm}$.

The highest tubers hill ${ }^{-1}$ was observed in $30 \pm 2 \mathrm{~g}$ tuber weight with $60 \mathrm{~cm} \times 25 \mathrm{~cm}$ spacing (8.60) and lowest from $10 \pm 2 \mathrm{~g}$ tuber with $60 \mathrm{~cm} \times 15 \mathrm{~cm}$ spacing (6.40) (Fig. 1). Results presented in Table 1 revealed that single tuber weight increased with increasing seed tuber weight till $30 \pm 2$ $\mathrm{g}$ seed tuber followed by no increment was observed. The higher single tuber weight was observed in $30 \pm 2 \mathrm{~g}$ and $40 \pm$ $2 \mathrm{~g}$ seed tuber with being the highest in $30 \pm 2 \mathrm{~g}$ seed tuber $(52.13 \mathrm{~g})$ and lowest from $10 \pm 2 \mathrm{~g}(30.13 \mathrm{~g})$. Results showed that single tuber weight decreased with decreasing plant spacing (Table 1). The largest tuber was observed in wider spacing, $60 \mathrm{~cm} \times 25 \mathrm{~cm}(48.70 \mathrm{~g})$ followed by the plant spacing of $60 \mathrm{~cm} \times 20 \mathrm{~cm}(44.75 \mathrm{~g})$ and lowest from $60 \mathrm{~cm} \times$ $15 \mathrm{~cm}(41.24 \mathrm{~g})$. The larger tuber in wider spacing was probably due to less competition among the plants for space, light, water and nutrients which were facilitated to faster growth and development of tuber thereby increase tuber size in wider spacing as compared to closer spacing [12]. The highest single tuber weight was recorded from $60 \mathrm{~cm} \times 25$ $\mathrm{cm}$ plant spacing with $40 \pm 2 \mathrm{~g}$ seed tuber $(60.20 \mathrm{~g})$ followed by the treatment combination of $60 \mathrm{~cm} \times 25 \mathrm{~cm}$ plant spacing with $30 \pm 2 \mathrm{~g}$ seed tuber $(55.0 \mathrm{~g})$ and lowest from $60 \mathrm{~cm} \times 15$ $\mathrm{cm}$ plant spacing with $10 \mathrm{~g}$ seed tuber $(29.0 \mathrm{~g})$ in (Fig. 1). Result revealed that tuber weight hill ${ }^{-1}$ increased with increasing seed tuber weight upto $30 \pm 2 \mathrm{~g}$ seed tuber followed by decline trend (Table 1). The higher tuber weight hill $^{-1}$ was observed in $30 \pm 2$ and $40 \pm 2 \mathrm{~g}$ seed tuber with being the highest in $30 \pm 2 \mathrm{~g}$ seed tuber $\left(317.2 \mathrm{~g} \mathrm{hill}^{-1}\right)$ and lowest $10 \pm 2 \mathrm{~g}\left(146.0 \mathrm{~g} \mathrm{hill}^{-1}\right)$. The lesser tuber weight in smaller size seed tuber might be due to fewer tubers hill ${ }^{-1}$ and smaller weight tuber [13].

Results showed that tuber weight decreased with decreasing plant spacing in (Table 1). The highest tuber weight hill ${ }^{-1}$ was observed in wider spacing, $60 \mathrm{~cm} \times 25 \mathrm{~cm}$ $\left(293.8 \mathrm{~g} \mathrm{hill}^{-1}\right)$ followed by the plant spacing of $60 \mathrm{~cm} \times 20$ $\mathrm{cm}\left(258.9 \mathrm{~g} \mathrm{hill}^{-1}\right)$ and lowest from $60 \mathrm{~cm} \times 15 \mathrm{~cm}(209.0 \mathrm{~g}$ hill $^{-1}$ ). The higher tuber yield hill ${ }^{-1}$ in wider spacing was probably due to higher number of tubers hill ${ }^{-1}$ and larger tuber [12]. In Fig. 1, the highest tuber weight hill $^{-1}$ was recorded in the treatment combination of $60 \mathrm{~cm} \times 25 \mathrm{~cm}$ plant spacing with $40 \pm 2 \mathrm{~g}$ seed tuber $\left(388.3 \mathrm{~g}^{\text {hill }}{ }^{-1}\right)$ followed by the treatment combination of $60 \mathrm{~cm} \times 25 \mathrm{~cm}$ plant spacing with $30 \pm 2 \mathrm{~g}$ seed tuber $\left(328.9 \mathrm{~g} \mathrm{hill}^{-1}\right)$ and lowest from $60 \mathrm{~cm} \times 15 \mathrm{~cm}$ plant spacing with $10 \pm 2 \mathrm{~g}$ seed tuber $\left(139.2 \mathrm{~g} \mathrm{hill}^{-1}\right)$. Result revealed that gross tuber yield increased with increasing seed tuber weight up to $25 \pm 2 \mathrm{~g}$ seed tuber. The highest gross tuber yield was observed in the seed tuber weight of $30 \pm 2 \mathrm{~g}\left(27.27 \mathrm{tha}^{-1}\right)$ followed by the seed tuber weight of $40 \pm 2 \mathrm{~g}\left(26.47 \mathrm{t} \mathrm{ha}^{-1}\right)$ with same statistical rank and lowest from $10 \pm 2 \mathrm{~g}\left(16.33 \mathrm{t} \mathrm{ha}^{-1}\right)$ in (Table 1).The gross tuber yield was lower in smaller weight seed tuber because of producing minimum tuber weight hill $^{-1}[13]$. The effect of plant spacing on gross tuber yield in potato was significant (Table 1). The highest gross tuber yield was observed in the plant spacing of $60 \mathrm{~cm} \times 20 \mathrm{~cm}$ $\left(23.92 \mathrm{tha}^{-1}\right)$ that was identical to the plant spacing of $60 \mathrm{~cm}$ $\times 25 \mathrm{~cm}\left(23.18 \mathrm{t} \mathrm{ha}^{-1}\right)$ and lowest $60 \mathrm{~cm} \times 15 \mathrm{~cm}(22.20 \mathrm{t}$ $\mathrm{ha}^{-1}$. Lower tuber yield per plant as well as per unit area under densely populated condition was might be due to lesser amount of assimilate produced by the plants through lesser photosynthetic area plant ${ }^{-1}$ and competition of nutrients uptake by the plants[12].The highest gross tuber yield $\mathrm{ha}^{-1}$ was recorded from $60 \mathrm{~cm} \times 25 \mathrm{~cm}$ plant spacing with $40 \pm 2 \mathrm{~g}$ seed tuber $\left(29.10 \mathrm{tha}^{-1}\right)$ followed by $60 \mathrm{~cm} \times$ $20 \mathrm{~cm}$ plant spacing with $30 \pm 2 \mathrm{~g}$ seed tuber $\left(28.20 \mathrm{tha}^{-1}\right)$ and lowest from $60 \mathrm{~cm} \times 25 \mathrm{~cm}$ plant spacing with $10 \pm 2 \mathrm{~g}$ 
seed tuber $\left(14.70 \mathrm{t} \mathrm{ha}^{-1}\right)$ (Fig. 1).It may be concluded that, the seed tuber weight and spacing influenced the seedling tuber performance as a whole, but from economic point of view, the seedling tuber weight of $30 \pm 2 \mathrm{~g}$ with plant spacing of 60 $\mathrm{cm} \times 20 \mathrm{~cm}$ was more profitable than those of other treatment combinations.

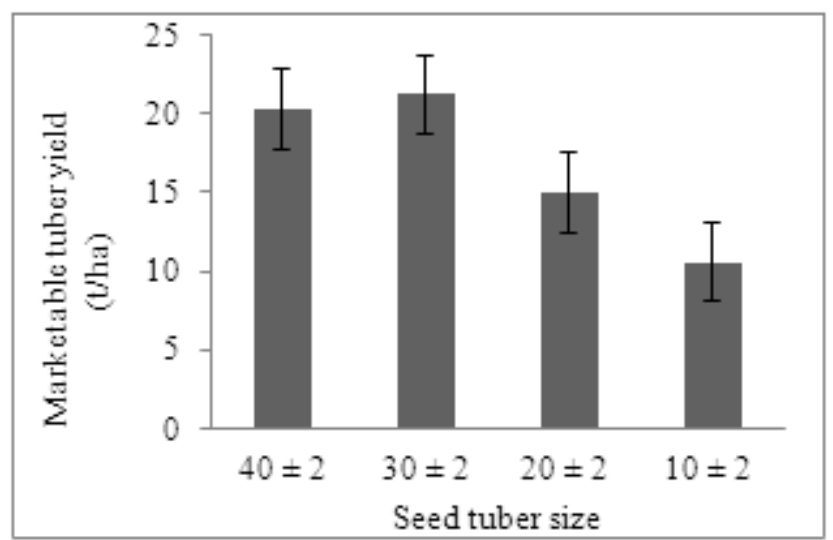

Figure 2. Effect of seed tuber size on marketable yield of potato. Vertical bar represent $\mathrm{SE}$ value (1.5). $\mathrm{T}_{1}=40 \pm 2 \mathrm{~g} ; \mathrm{T}_{2}=30 \pm 2 \mathrm{~g} ; \mathrm{T}_{3}=20 \pm 2 \mathrm{~g} ; \mathrm{T}_{4}=$ $10 \pm 2 \mathrm{~g}$.

Result revealed that marketable tuber yield increased with increasing seed tuber weight till $30 \pm 2 \mathrm{~g}$ seed tuber followed by slight decline in (Fig. 2). The highest marketable yield of tubers was observed in the seed tuber size of $30 \pm 2 \mathrm{~g}(21.28$ $\left.\mathrm{t} \mathrm{ha}^{-1}\right)$ followed by the seed tuber weight of $40 \pm 2 \mathrm{~g}(20.31 \mathrm{t}$ $\mathrm{ha}^{-1}$ ) with same statistical rank and lowest from $10 \pm 2 \mathrm{~g}$ $\left(10.52 \mathrm{t} \mathrm{ha}^{-1}\right)$. It was primarily due to high food reserves in large seed tubers which ultimately contributed to produce high yield through increase vegetative growth of plants and rapid development of tubers [9].

Fig. 3 shows that the highest marketable tuber yield was observed in the plant spacing of $60 \mathrm{~cm} \times 20 \mathrm{~cm}\left(17.79 \mathrm{tha}^{-1}\right)$ that was identical to the plant spacing of $60 \mathrm{~cm} \times 25 \mathrm{~cm}$ $\left(17.75 \mathrm{tha}^{-1}\right)$ and lowest from $60 \mathrm{~cm} \times 15 \mathrm{~cm}\left(15.32 \mathrm{t} \mathrm{ha}^{-1}\right)$.
Lower marketable tuber yield per unit area under densely populated condition was might be due to lesser amount of assimilate produced by the plants through lesser photosynthetic area plant ${ }^{-1}$ and competition of nutrients uptake by the plants [14].

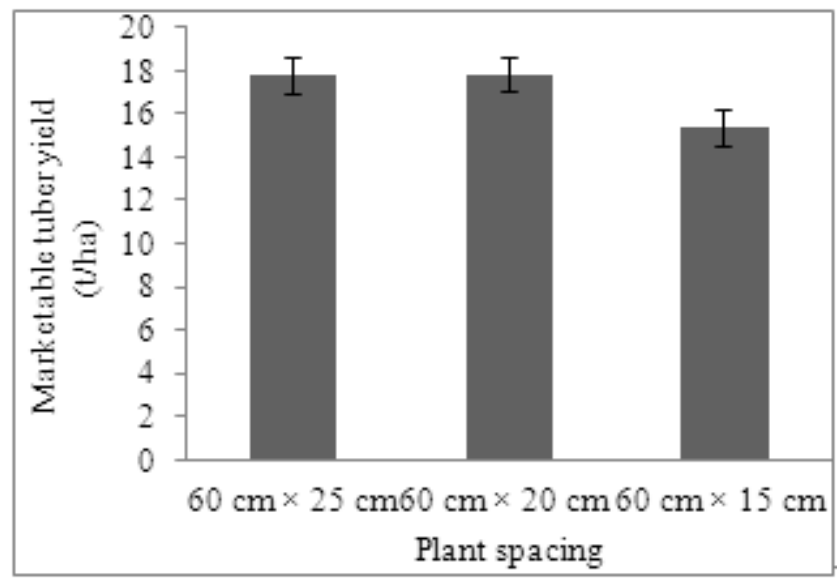

Figure 3. Effect of plant spacing on marketable yield in potato. Vertical bar represent $\mathrm{SE}$ value (1.3). $\mathrm{S}_{1}=60 \mathrm{~cm} \times 25 \mathrm{~cm} ; \mathrm{S}_{2}=60 \mathrm{~cm} \times 20 \mathrm{~cm} ; \mathrm{S}_{3}=$ $60 \mathrm{~cm} \times 15 \mathrm{~cm}$.

The interaction effect of seed tuber size and plant spacing on marketable tuber yield ha-1 was significant (Fig. 4). The highest marketable tuber yield $\mathrm{ha}^{-1}$ was recorded in the treatment combination of $60 \mathrm{~cm} \times 25 \mathrm{~cm}$ plant spacing with $40 \pm 2 \mathrm{~g}$ seed tuber $\left(23.28 \mathrm{tha}^{-1}\right)$ followed by the treatment combination of $60 \mathrm{~cm} \times 25 \mathrm{~cm}$ plant spacing with $30 \pm 2 \mathrm{~g}$ seed tuber $\left(22.96 \mathrm{t} \mathrm{ha}^{-1}\right)$. The lowest marketable tuber yield $\mathrm{ha}^{-1}$ was recorded in the treatment combination of $60 \mathrm{~cm} \times 25$ $\mathrm{cm}$ plant spacing with $10 \pm 2 \mathrm{~g}$ seed tuber $\left(10.14 \mathrm{t} \mathrm{ha}^{-1}\right)$ that was statistically similar to the treatment combination of 60 $\mathrm{cm} \times 20 \mathrm{~cm}$ plant spacing with $10 \pm 2 \mathrm{~g}$ seed tuber $(10.85 \mathrm{t}$ $\mathrm{ha}^{-1}$ ) and $60 \mathrm{~cm} \times 15 \mathrm{~cm}$ plant spacing with $10 \pm 2 \mathrm{~g}$ seed tuber $\left(10.56 \mathrm{t} \mathrm{ha}^{-1}\right)$.

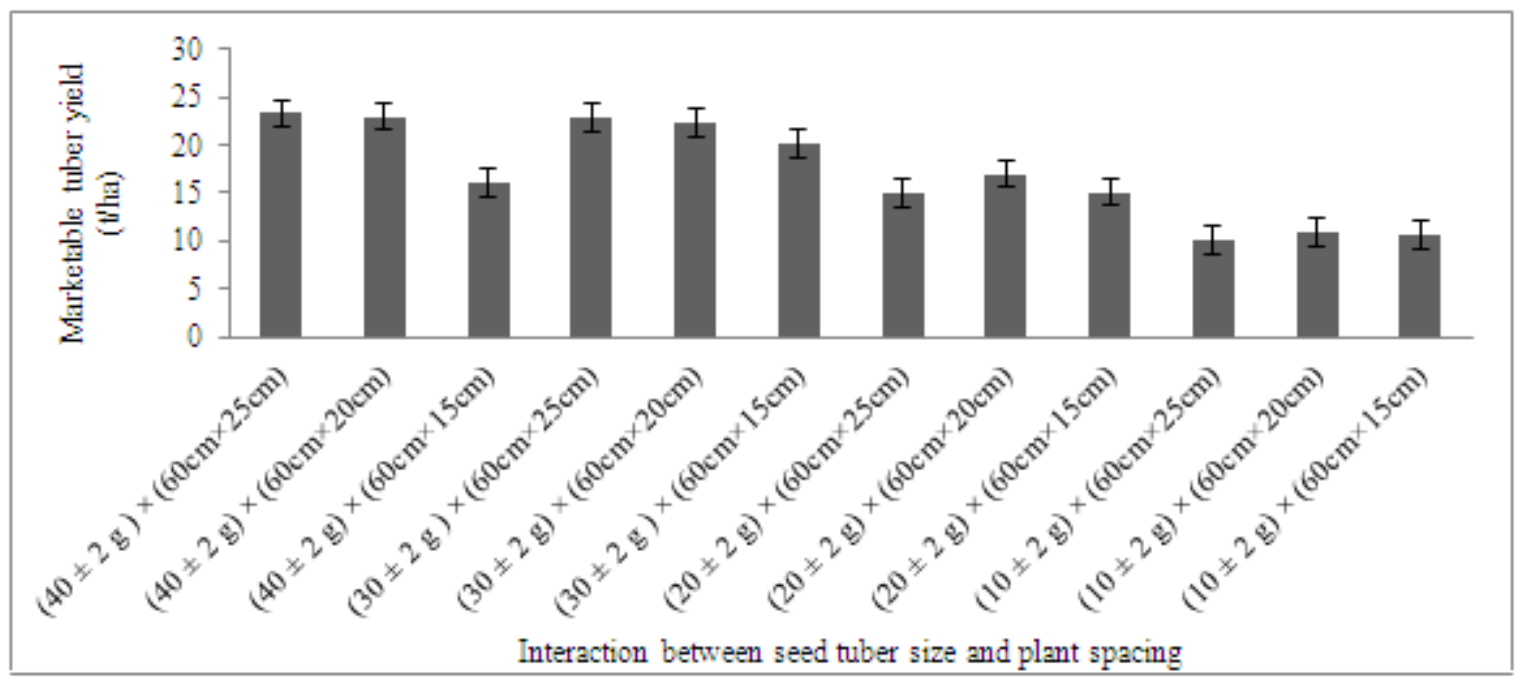

Figure 4. Interaction effect of seed tuber size and plant spacing on tuber marketable yield in potato. Vertical bar represents $\mathrm{SE}$ value $(0.74)$. $\mathrm{T}_{1}=40 \pm 2 \mathrm{~g}$; $\mathrm{T}_{2}=30 \pm$ $2 \mathrm{~g} ; \mathrm{T}_{3}=20 \pm 2 \mathrm{~g} ; \mathrm{T}_{4}=10 \pm 2 \mathrm{~g} ; \mathrm{S}_{1}=60 \mathrm{~cm} \times 25 \mathrm{~cm} ; \mathrm{S}_{2}=60 \mathrm{~cm} \times 20 \mathrm{~cm} ; \mathrm{S}_{3}=60 \mathrm{~cm} \times 15 \mathrm{~cm}$. 
There was a significant difference in non-marketable yield of tubers due to seed tuber size (Fig. 5). The highest non-marketable yield of tubers was observed in the seed tuber size of $20 \pm 2 \mathrm{~g}\left(7.15 \mathrm{t} \mathrm{ha}^{-1}\right)$ followed by the seed tuber size of $40 \pm 2 \mathrm{~g}\left(6.15 \mathrm{t} \mathrm{ha}^{-1}\right)$ and lowest from $30 \pm 2 \mathrm{~g}(5.40 \mathrm{t}$ $\left.\mathrm{ha}^{-1}\right)$. Lower non-marketable tuber yield per unit area under thin populated condition was might be due to available amount of assimilate produced by the plants through increase photosynthetic area plant ${ }^{-1}$ and less competition of nutrients uptake by the plants [15].

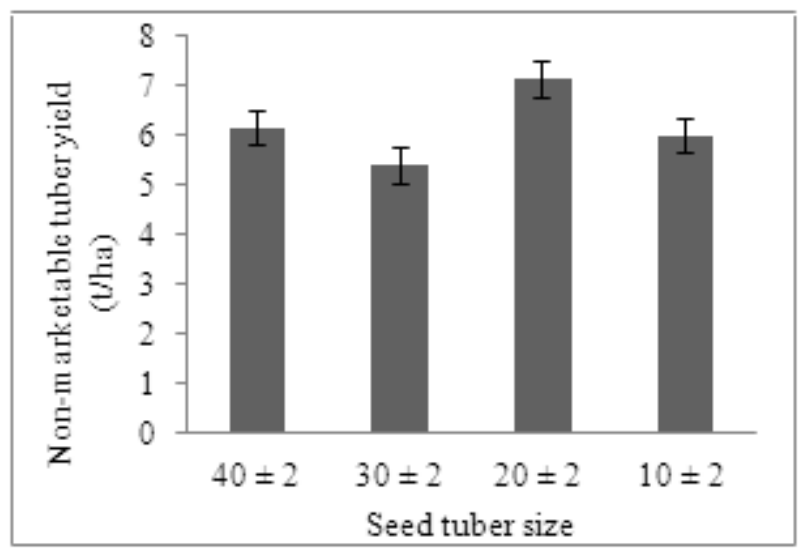

Figure 5. Effect of seed tuber size on non-marketable yield in potato. Vertical bar represent SE value (0.51). $\mathrm{T}_{1}=40 \pm 2 \mathrm{~g} ; \mathrm{T}_{2}=30 \pm 2 \mathrm{~g} ; \mathrm{T}_{3}=20 \pm$ $2 \mathrm{~g} ; \mathrm{T}_{4}=10 \pm 2 \mathrm{~g}$.

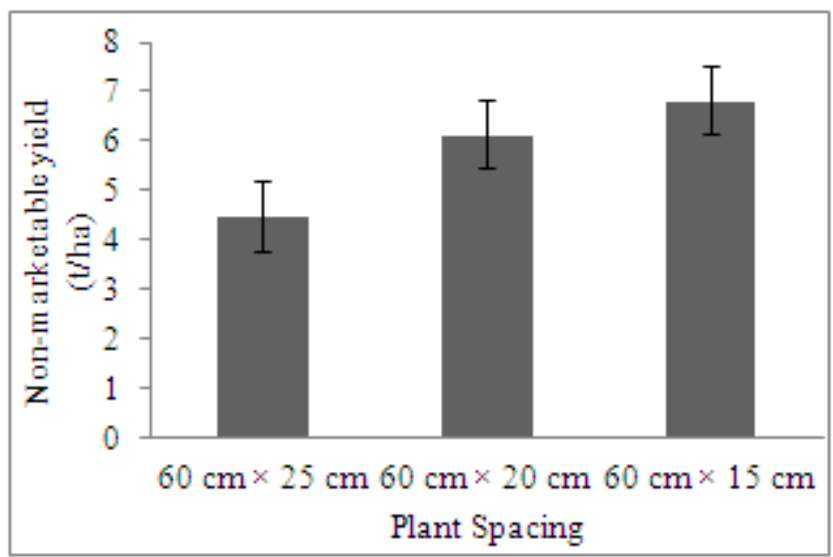

Figure 6. Effect of plant spacing on non-marketable yield in potato. Vertical bar represent SE value (0.52). $\mathrm{S}_{1}=60 \mathrm{~cm} \times 25 \mathrm{~cm} ; \mathrm{S}_{2}=60 \mathrm{~cm}$ $\times 20 \mathrm{~cm} ; \mathrm{S}_{3}=60 \mathrm{~cm} \times 15 \mathrm{~cm}$.
In Fig. 6, results showed that non-marketable tuber yield increased with decreasing plant spacing. The highest non-marketable tuber yield was observed in the plant spacing of $60 \mathrm{~cm} \times 15 \mathrm{~cm}\left(6.80 \mathrm{tha}^{-1}\right)$ followed by the plant spacing of $60 \mathrm{~cm} \times 20 \mathrm{~cm}\left(6.12 \mathrm{t} \mathrm{ha}^{-1}\right)$ and lowest from $60 \mathrm{~cm} \times 25$ $\mathrm{cm}\left(4.46 \mathrm{t} \mathrm{ha}^{-1}\right)$. This results also supported by [16].

The interaction effect of seed tuber size and plant spacing on non-marketable tuber yield $\mathrm{ha}^{-1}$ was significant (Fig. 7).The highest non-marketable tuber yield ha ${ }^{-1}$ from $60 \mathrm{~cm} \times$ $15 \mathrm{~cm}$ plant spacing with $20 \pm 2 \mathrm{~g}$ seed tuber $\left(7.91 \mathrm{t} \mathrm{ha}^{-1}\right)$ followed by $60 \mathrm{~cm} \times 25 \mathrm{~cm}$ plant spacing with $20 \pm 2 \mathrm{~g}$ seed tuber $\left(7.28 \mathrm{t} \mathrm{ha}^{-1}\right)$ and lowest from $60 \mathrm{~cm} \times 25 \mathrm{~cm}$ plant spacing with $10 \pm 2 \mathrm{~g}$ seed tuber $\left(4.51 \mathrm{tha}^{-1}\right)$.

It was observed that there was significant variation in size grade of tubers due to different seed tuber weight (Table 2). The highest number of Grade-A and Grade-B tuber was recorded in the seed tuber size of $40 \pm 2 \mathrm{~g}(18.4 \%$ and $38.83 \%$ for grade-A and grade-B, respectively). The highest number of Grade-C and Grade-D tuber was recorded in the seed tuber size of $10 \pm 2 \mathrm{~g}(45.04 \%$ and $37.37 \%$ for grade-C and grade-D, respectively) and lowest from $40 \pm 2 \mathrm{~g}$ $(31.13 \% \%$ and $11.68 \%$ for grade-C and grade-D, respectively). This results also supported by [17].Tuber size was significantly affected by plant spacing (Table 2). Results revealed that greater number of larger tuber (grade-A \& B) was produced in wider spacing, $60 \mathrm{~cm} \times 25 \mathrm{~cm}(10.5$ and $34.70 \%$ for grade-A and grade-B, respectively) followed by the plant spacing of $60 \mathrm{~cm} \times 20 \mathrm{~cm}$ and lowest from $60 \mathrm{~cm} \times$ $15 \mathrm{~cm}(4.80 \%$ and $25.43 \%$ for grade-A and grade-B, respectively). On the contrary, the highest number of smaller size tuber was produced in the closer spacing of $60 \mathrm{~cm} \times 15$ $\mathrm{cm}(43.95 \%$ and $25.83 \%$ for grade-C and grade-D, respectively). This results supported by [18].The interaction effect of seed tuber size and plant spacing on tuber grade distribution was significant (Fig. 8). The highest number of Grade-A and Grade-B tuber was recorded in $40 \pm 2 \mathrm{~g}$ seed tuber with plant spacing of $60 \mathrm{~cm} \times 30 \pm 2 \mathrm{~cm}(24.10 \%$ and $45.20 \%$ for grade- $\mathrm{A}$ and grade- $\mathrm{B}$, respectively). The highest number of Grade-C tuber was recorded in $10 \pm 2 \mathrm{~g}$ seed tuber with plant spacing of $60 \mathrm{~cm} \times 25 \mathrm{~cm}(47.31 \%)$ and Grade-D tuber was recorded in $10 \mathrm{~g}$ seed tuber with plant spacing of $60 \mathrm{~cm} \times 15 \mathrm{~cm}(42.0 \%)$ and lowest from $40 \pm 2 \mathrm{~g}$ seed tuber with plant spacing of $60 \mathrm{~cm} \times 25 \mathrm{~cm}(9.74 \%$ and $21.0 \%$ for grade-D and grade-C, respectively). 


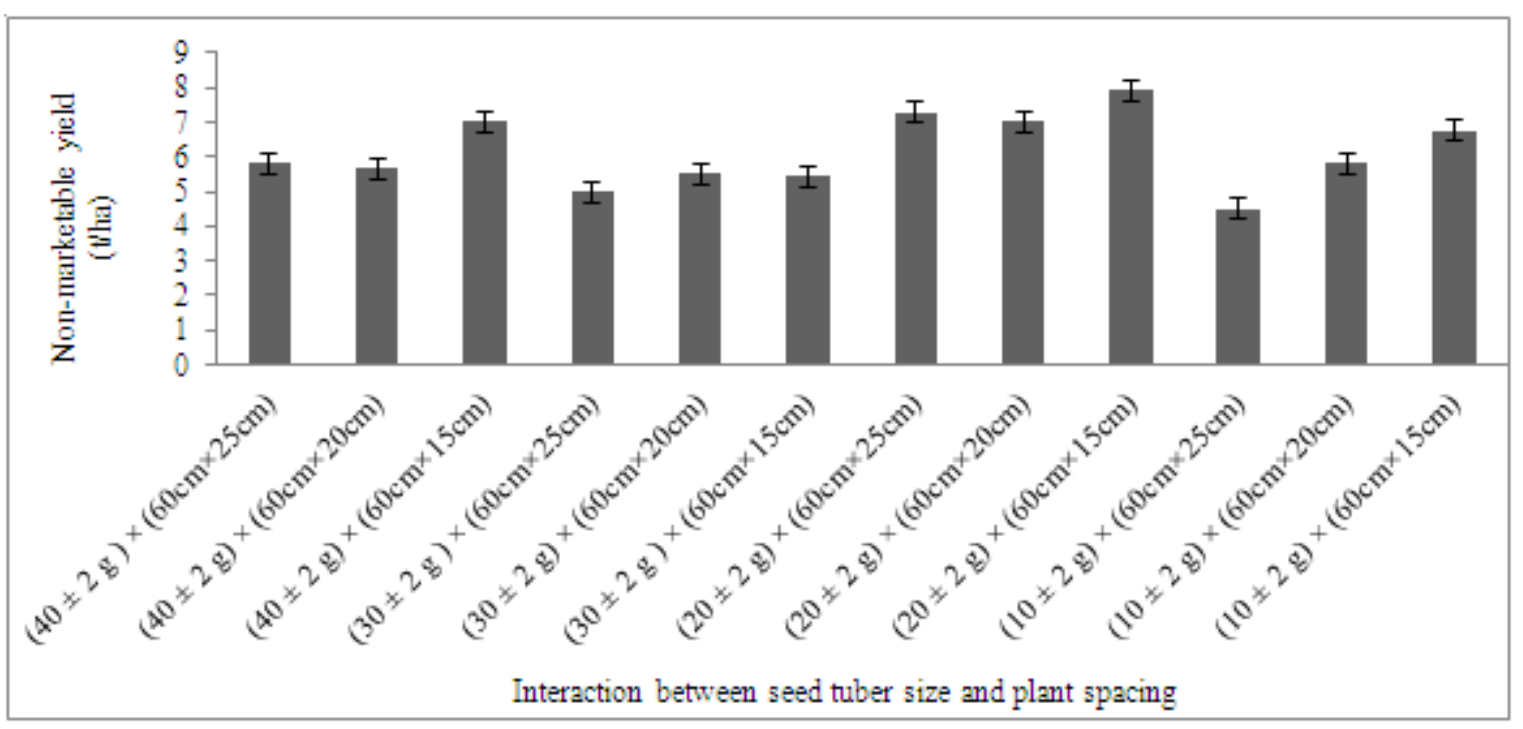

Figure 7. Interaction effect of seed tuber size and plant spacing on non-marketable Tuber yield in potato. Vertical bar represents $\mathrm{SE}$ value $(0.25)$. $\mathrm{T}_{1}=40$ $\pm 2 \mathrm{~g} ; \mathrm{T}_{2}=30 \pm 2 \mathrm{~g} ; \mathrm{T}_{3}=20 \pm 2 \mathrm{~g} ; \mathrm{T}_{4}=10 \pm 2 \mathrm{~g} ; \mathrm{S}_{1}=60 \mathrm{~cm} \times 25 \mathrm{~cm} ; \mathrm{S}_{2}=60 \mathrm{~cm} \times 20 \mathrm{~cm} ; \mathrm{S}_{3}=60 \mathrm{~cm} \times 15 \mathrm{~cm}$.

Table 2. Effect of seed tuber weight and plant spacing on the grade of tubers by number in potato

\begin{tabular}{|c|c|c|c|c|}
\hline \multirow{2}{*}{ Tuber weight } & \multicolumn{4}{|c|}{ Grade of tubers (\%) by number } \\
\hline & $<20 \mathrm{~mm}$ & $20-35 \mathrm{~mm}$ & $35-55 \mathrm{~mm}$ & $>55 \mathrm{~mm}$ \\
\hline $40 \pm 2 \mathrm{~g}$ & $11.68 \mathrm{~d}$ & $31.13 \mathrm{~d}$ & $38.83 \mathrm{a}$ & $18.4 \mathrm{a}$ \\
\hline $30 \pm 2 \mathrm{~g}$ & $18.53 \mathrm{c}$ & $37.07 \mathrm{c}$ & $36.30 \mathrm{~b}$ & $8.10 \mathrm{~b}$ \\
\hline $20 \pm 2 \mathrm{~g}$ & $21.40 \mathrm{~b}$ & $41.50 \mathrm{~b}$ & $31.73 \mathrm{c}$ & $5.37 \mathrm{c}$ \\
\hline $10 \pm 2 \mathrm{~g}$ & $37.37 \mathrm{a}$ & $45.04 \mathrm{a}$ & $17.13 \mathrm{~d}$ & $0.46 \mathrm{~d}$ \\
\hline F-test & *** & *** & ** & ** \\
\hline SE & 0.677 & 0.993 & 0.799 & 0.225 \\
\hline \multicolumn{5}{|l|}{ Spacing } \\
\hline $60 \mathrm{~cm} \times 25 \mathrm{~cm}$ & $20.01 \mathrm{~b}$ & $34.78 \mathrm{c}$ & $34.70 \mathrm{a}$ & $10.5 \mathrm{a}$ \\
\hline $60 \mathrm{~cm} \times 20 \mathrm{~cm}$ & $20.90 \mathrm{~b}$ & $37.33 \mathrm{~b}$ & $32.88 \mathrm{a}$ & $8.90 \mathrm{~b}$ \\
\hline $60 \mathrm{~cm} \times 15 \mathrm{~cm}$ & $25.83 \mathrm{a}$ & $43.95 \mathrm{a}$ & $25.43 \mathrm{~b}$ & $4.80 \mathrm{c}$ \\
\hline F-test & $* *$ & $* *$ & $* *$ & $* *$ \\
\hline SE & 0.586 & 0.860 & 0.692 & 0.195 \\
\hline CV (\%) & 9.14 & 7.70 & 7.74 & 8.38 \\
\hline
\end{tabular}

In a column means having similar letter(s) are statistically similar and those having dissimilar letter(s) differ significantly at 0.05 level of probability.*; ** indicate significant at $5 \%$ and $1 \%$ level of probability, respectively. $\mathrm{T}_{1}=40 \pm 2 \mathrm{~g} ; \mathrm{T}_{2}=30 \pm 2 \mathrm{~g} ; \mathrm{T}_{3}=20 \pm 2 \mathrm{~g} ; \mathrm{T}_{4}=10 \pm 2 \mathrm{~g} ; \mathrm{S}_{1}=60 \mathrm{~cm} \times 25 \mathrm{~cm} ; \mathrm{S}_{2}=60 \mathrm{~cm}$ $\times 20 \mathrm{~cm} ; \mathrm{S}_{3}=60 \mathrm{~cm} \times 15 \mathrm{~cm}$.

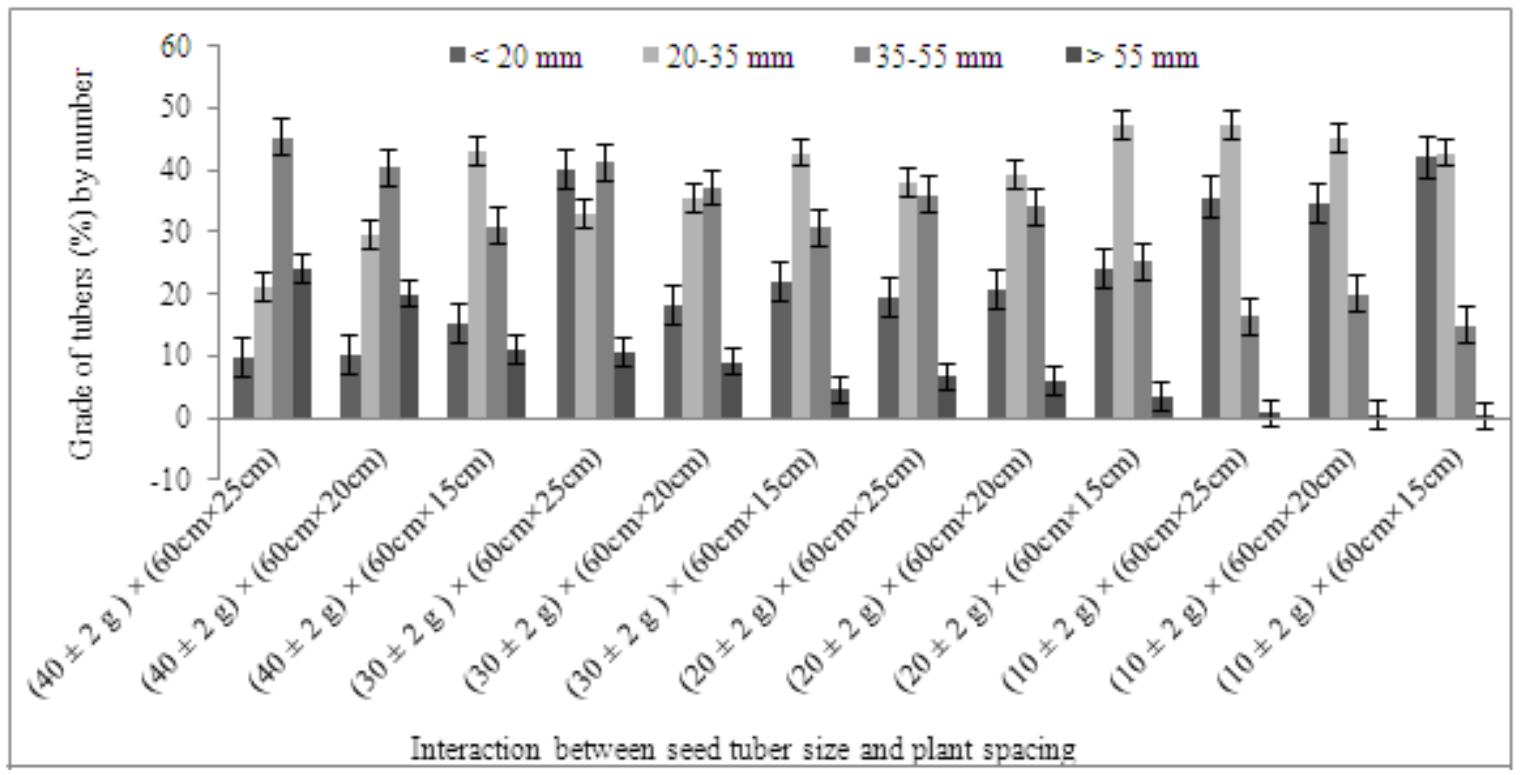

Figure 8. Interaction effect of seed tuber size and plant spacing on grade of tubers (\%) by number. Vertical bar represents SE value $(1.173,1.720,1.385$ and 0.390). $\mathrm{T}_{1}=40 \pm 2 \mathrm{~g} ; \mathrm{T}_{2}=30 \pm 2 \mathrm{~g} ; \mathrm{T}_{3}=20 \pm 2 \mathrm{~g} ; \mathrm{T}_{4}=10 \pm 2 \mathrm{~g} ; \mathrm{S}_{1}=60 \mathrm{~cm} \times 25 \mathrm{~cm} ; \mathrm{S}_{2}=60 \mathrm{~cm} \times 20 \mathrm{~cm} ; \mathrm{S}_{3}=60 \mathrm{~cm} \times 15 \mathrm{~cm}$. 
Table 3. Economic analysis in potato production as influenced by tuber size and spacing

\begin{tabular}{|c|c|c|c|c|c|}
\hline Treatments & $\begin{array}{l}\text { Seed rate } \\
\left(\mathrm{kg} \mathrm{ha}^{-1}\right)\end{array}$ & $\begin{array}{c}\text { Cost of cultivation } \\
\text { ha }^{-1} \\
\text { (in US \$) }\end{array}$ & $\begin{array}{l}\text { Gross return ha-1 } \\
\quad \text { (in US \$) }\end{array}$ & $\begin{array}{l}\text { Net profit ha }{ }^{-1} \\
\quad \text { (in US \$) }\end{array}$ & Benefit cost ratio \\
\hline \multicolumn{6}{|c|}{$40 \pm 2$ g size tuber } \\
\hline $60 \mathrm{~cm} \times 25 \mathrm{~cm}$ & 2333 & 2763.07 & 9414.22 & 6651.28 & 2.41 \\
\hline $60 \mathrm{~cm} \times 20 \mathrm{~cm}$ & 2917 & 3087.1 & 8831.9 & 5744.8 & 1.86 \\
\hline $60 \mathrm{~cm} \times 15 \mathrm{~cm}$ & 3889 & 3611.97 & 7440.79 & 3828.95 & 1.06 \\
\hline \multicolumn{6}{|c|}{$30 \pm 2 \quad$ g size tuber } \\
\hline $60 \mathrm{~cm} \times 25 \mathrm{~cm}$ & 1667 & 2896.6 & 8508.39 & 6111.79 & 2.55 \\
\hline $60 \mathrm{~cm} \times 20 \mathrm{~cm}$ & 2083 & 2627.45 & 9123.06 & 6495.61 & 2.47 \\
\hline $60 \mathrm{~cm} \times 15 \mathrm{~cm}$ & 2778 & 3002.73 & 8281.93 & 5279.2 & 1.76 \\
\hline \multicolumn{6}{|c|}{$20 \pm 2 \mathrm{~g}$ size tuber } \\
\hline $60 \mathrm{~cm} \times 25 \mathrm{~cm}$ & 1333 & 2212.84 & 6761.42 & 4548.58 & 2.05 \\
\hline $60 \mathrm{~cm} \times 20 \mathrm{~cm}$ & 1667 & 2398.15 & 7602.55 & 5204.4 & 2.17 \\
\hline $60 \mathrm{~cm} \times 15 \mathrm{~cm}$ & 2222 & 2697.87 & 7311.39 & 4613.54 & 1.71 \\
\hline \multicolumn{6}{|c|}{$10 \pm 2 \mathrm{~g}$ size tuber } \\
\hline $60 \mathrm{~cm} \times 25 \mathrm{~cm}$ & 667 & 1846.36 & 4755.64 & 2909.27 & 1.58 \\
\hline $60 \mathrm{~cm} \times 20 \mathrm{~cm}$ & 833 & 1938.5 & 5402.66 & 3494.16 & 1.78 \\
\hline $60 \mathrm{~cm} \times 15 \mathrm{~cm}$ & 1110 & 2088.61 & 5693.82 & 3605.21 & 1.73 \\
\hline
\end{tabular}

Variation in cost of production was noticed due to the cost of seed tuber and different plant spacing (Table 3 ). The total cost of cultivation ranged between $\$ 1846.36$ and $\$ 3611.97$. The cultivation cost increased with increasing seed tuber size and decreasing plant spacing. The highest cost of production was involved when used $40 \pm 2 \mathrm{~g}$ seed tuber with closer spacing of $60 \mathrm{~cm} \times 15 \mathrm{~cm}(\$ 3611.97)$ and lowest from $10 \pm 2$ $\mathrm{g}$ seed tuber with wider spacing of $60 \mathrm{~cm} \times 25 \mathrm{~cm}$ ( $\$$ 1846.36). The highest gross return from $40 \pm 2 \mathrm{~g}$ seed tuber with wider spacing of $60 \mathrm{~cm} \times 25 \mathrm{~cm}(\$ 9414.22)$ that was apparently similar to the treatment combination of $30 \pm$ $2 \mathrm{~g}$ seed tuber with plant spacing of $60 \mathrm{~cm} \times 20 \mathrm{~cm}(9123.06)$ and lowest from $10 \pm 2 \mathrm{~g}$ seed tuber with wider spacing of 60 $\mathrm{cm} \times 25 \mathrm{~cm}$ (4755.64). However, the highest net profit from $40 \pm 2 \mathrm{~g}$ seed tuber with wider spacing of $60 \mathrm{~cm} \times 25 \mathrm{~cm}$ (\$6651.28) that was apparently similar to $30 \pm 2 \mathrm{~g}$ seed tuber with plant spacing of $60 \mathrm{~cm} \times 20 \mathrm{~cm}(\$ 6495.61)$. The maximum benefit-cost ratio was observed in those two treatment combination (2.41-2.47). The lowest net profit and benefit-cost ratio was observed in the treatment combination of $10 \pm 2 \mathrm{~g}$ seed tuber with plant spacing of $60 \mathrm{~cm} \times 25 \mathrm{~cm}$ (\$2909.27 and 1.58, respectively).

\section{Conclusions}

Potato yield and economic return mostly influenced by many production factors, among these seed tuber weight and spacing is most important. Finally it may be concluded that, different tuber weight and spacing significantly influence the yield and economic return of seedling tuber. But from economic point of view with high yield performance, the seedling tuber size of $30 \pm 2 \mathrm{~g}$ with plant spacing of $60 \mathrm{~cm} \times$ $20 \mathrm{~cm}$ was more profitable than those of other treatment combinations.

\section{Acknowledgements}

The authors are very much thankful to Ministry of Education, Republic of Bangladesh to provide financial support for this study.

\section{REFERENCES}

[1] FAOSTAT.Statistical Database.Food and Agricultural Organization of United Nations, Rome, Italy, 2012.

[2] Bangladesh Bureau of Statistic (BBS).Agricultural Statistics Yearbook-2011, 2012.

[3] FAO. Production Year Book No. 65. Food and Agriculture Organization FAO (1988), Rome, Italy.p. 97, 2007.

[4] Divis, J. and Barta, J. Influence of the seed-tuber size on yield and yield parameters in potatoes. RostlinnaVyroba, 47(6): 271-275, 2001.

[5] TCRC. Annual Report of 2003-04. Tuber Crops Research Centre, Bangladesh Agricultural Research Institute, Gazipur-1701. p.13, 2004.

[6] Wiersema, S. G. The production and utilization of seed tubers derived from true potato seed. Ph. D. Thesis. Univ. Reading, U. K. p. 229, 1984.

[7] BongKyoon, K. Youngkil, K. and Mira, K. Effect of seed potato size on plug seedling growth and field performance. Korean J. Crop Sci. 46(2): 121-124, 2001.

[8] Conley, S. P., Binning, L. K., and Connell, T.R. Effect of cultivar, row spacing, and weed management on weed biomass, potato yield, and net crop value. Amer J. Pot Res. 78(1): 31-37, 2001.

[9] Malik, Y. S., Bhatia, A.K., Singh, N., Nehra, B. K and 
Khurana, S. C. Effect of nitrogen, seed size and spacing on seed potato production in cv. Kufri Sutlej.potato, global research and development. Proceedings of the Global Conf. on Potato. Dec 6-11. New Delhi, India, 2: 861-865, 2002.

[10] Rashid, M. M. Problems of production of true potato seeds in Bangladesh. Pro. On true potato seed research in Bangladesh, Oct. 5-7, BARI, Gazipur-1701. pp. 5-7, 1987.

[11] Yenagi, B. S., Meli, S. S, Angadi, S. S, Prabhakar, A. S. N and Basavaraj, B. Effects of row spacing date of planting and levels of nitrogen on yield of potato. Karnataka J. Agric. Sci. 15(1): 134-135, 2002.

[12] Ghosh, S. C., Asanuma, K., Kusutani, A. and Toyota, M. Effects of shading on dry matter production, yield and nitrate reductase activity of potato under two levels of spacing. Environment Control in Biology. 40(3): 259-268, 2002.

[13] Gregoriou, S. The effect of row spacing on yield and tuber size distribution of the potato cv. Cara. Tech. Bull. Cyprus Agric. Res. Ins. 207:1-10, 2000.
[14] Khurana, S. C. and Bhutani, R. D. Effect of spacing, fertilizer dose and crop duration on the production of seed size tubers in potato (Solanumtuberosum L.). Haryana J. Hort. Sci. 32(3/4): 259-261, 2003.

[15] Verma, V, Varshney,S. K, Singh, B and Kumar, A. Effect of seedling tuberlet size on seed potato yield of TPS varieties in calcareous soils of north Bihar. Ann. Biol. 23(2): pp.137-139, 2007.

[16] Suman, S, Malik,Y. S and Khurana, S. C. Effect of fertilizer, spacing and crop duration on growth and yield of potato. J. Indian Potato Assoc. 30(1/2): 87-88, 2003.

[17] Grewal, J. S., Sharma, R. C. and Saini, S. S. Agrotechniques for intensive potato cultivation in India. Indian Council of Agric. Res., New Delhi. pp.26-28, 1992.

[18] Wadhwa, B. K, Pandita, M. L and Khurana, S. C. Effect of spacing on ware crop of potato raised from seedlings. J. Indian Potato Assoc., 27(1/2): 45-46, 2000. 